\title{
Drawing out the Essential Business of Ports
}

\author{
Rasha Ismail Fady ${ }^{1}$ and lan Beeson ${ }^{2}$ \\ ${ }^{1}$ Arab Academy for Science \& Technology, Alexandria, Egypt \\ ${ }^{2}$ Bristol Institute of Technology, University of the West of England, Bristol, UK, BS16 1QY
}

\begin{abstract}
Process modelling is used to reveal the structure of business processes in a port. The method of process modelling used is Ould's Riva method and the port it is applied to is Alexandria Port in Egypt. The main advantages of this method are that an overall picture of the business of a complex organisation such as a port can be drawn, and that essential elements of the business can be distinguished from secondary elements. An initial process architecture of the business of Alexandria Port is developed from the essential elements, the most important of which are ship and shipment. The architecture makes visible ways in which processes connect with and may affect one another. An architecture derived from essential elements can serve as the basis for a comparison of Alexandria Port with other ports, or for a redesign of some of the processes in order to streamline the business or to introduce new technological support.
\end{abstract}

\section{The general business of ports}

Ports in general have some common activities that take place when a ship arrives at the outer anchorage. The traditional functions of the port were to facilitate the shipment loading/unloading and act as a platform for shipment transportation [4]. The port's functions are performed by different departments, which need to work in concert with one another.

The [10] current priority for ports is involvement in the supply chain. Internal integration of the port's departments and external integration with different parties in the supply chain have become important. 'Fourth generation' ports were defined [7], as those adopting a new logistics approach that is more agile.

Ports however have a complex organisational structure [10], which presents an obstacle to creating a general framework for the management of a port's processes. Analysis of a port's processes and roles might lead the way to a simplification of structure. Integration of material and information flow and better external coordination through such roles as shipping agent could lead to improvements in the supply chain.

Ports require accurate information about shipments to improve shipment management and support planning and decision making [2]. The introduction of electronic documents can assist the passage of secure information to and from ports among the supply chain [5]. By improving the information they can supply, ports are able to provide a value-added service [10]. Accuracy in information is however limited by the difficulty of comparing traffic totals when so many different types of commodities are handled and there is no standard computational format for handling. Containerisation, already popular because it leads to lower transportation cost and standardisation of commodity packaging, can also ease the information handling problem.

Containerisation has led to an increase in ship size and in income per ship, [3], but it requires larger port terminals to accommodate the ships. This in turn creates an increase in the container port traffic that needs to be planned by the port as it strives to facilitate truck movement and the growth of the port's container capacity. The increased number of containers entering and leaving the port creates more complexity in container handling that needs to be managed [8].

\section{The business of Alexandria Port}

Egyptian ports are managed overall by the Egyptian Maritime Transport Sector (EMTS) and Alexandria Port is directly managed by

Copyright (C) 2010 Rasha Ismail Fady, and Ian Beeson. This is an open access article distributed under the Creative Commons Attribution License unported 3.0, which permits unrestricted use, distribution, and reproduction in any medium, provided that original work is properly cited. The article is a reprint from a 2009 article. Contact author: Rasha Ismail Fady. E-mail: rashaf@aast.edu 
Alexandria Port Authority. Alexandria Port is the main port in the country and plays a vital role in the Egyptian economy.

\subsection{Characteristics of Alexandria Port}

Alexandria Port consists of two harbours, East and West, as shown in Figure 1. The West harbour is used for commercial shipping. Further information about Alexandria Port can be accessed on the government website [1]. The amount of imports and exports passing in and out of the port represent the majority of the country's trade. The port has an outer anchorage and an inner anchorage, and the width of the port's entrance is about 400 metres. Table 1 shows the types and numbers of berths at Alexandria.

\subsection{The general work of Alexandria Port}

The general flow of work through the port is described below, first for imported goods and then for exported goods. Important business entities that will be used in process modelling further on in the paper are marked in italics.

\section{Imported goods}

The shipping agent notifies the port authority about an arriving ship by providing a berthing order, which identifies all needed information about the ship including name, the shipping agent, the size of the ship and other details. The port authority plans the required tug boats, pilots and a suitable berth (which may have been recommended by the agent in the berthing order). The port authority after that waits for the manifest to arrive at least 24 hours before the ship's arrival. The manifest is sent to the central manifest department located in the customs department. The central manifest department distributes the manifest to all other authorities including the container handling company, stevedoring company (for general cargo), the warehouses and the customs and tests departments.

Table 1: Types and numbers of berths at Alexandria Port

\begin{tabular}{|l|l|}
\hline \multicolumn{1}{|c|}{ Berth Type } & $\begin{array}{c}\text { Number } \\
\text { of Berths }\end{array}$ \\
\hline General Cargo & 27 \\
\hline Passenger \& Tourist Terminal & 5 \\
\hline RO RO & 3 \\
\hline Military & 2 \\
\hline Container Terminal & 4 \\
\hline Fertilisers & 3 \\
\hline Molasses & 1 \\
\hline Provisions and Grains Terminal & 4 \\
\hline Coal Terminal & 3 \\
\hline Livestock & 1 \\
\hline Edible oil \& petroleum terminal & 5 \\
\hline Repair Docks & 2 \\
\hline Total & 60 \\
\hline
\end{tabular}




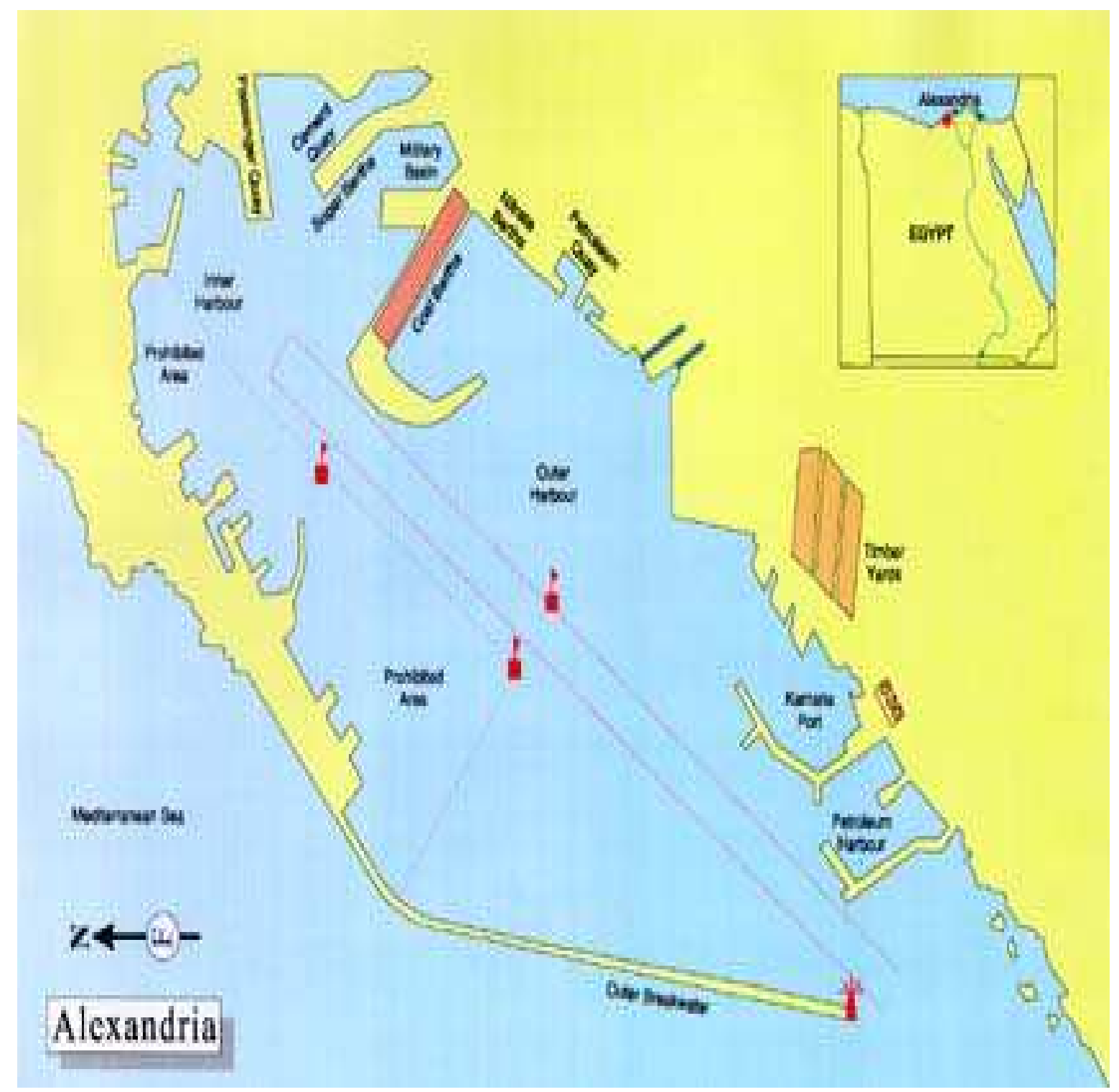

Figure 1: Alexandria Port map

The port authority plans the ship's berthing process in advance, based on the berthing order. The plan is put into action when the ship arrives to the outer anchorage of the port. Then the ship's captain sends an arrival notification to the tower in the berthing department. The tower acknowledges the berthing department and orders tug boats and pilots to move towards the arriving ship. The berthing department notifies the container handling company and the general cargo company about the ship's arrival.

If the ship's actual time of arrival changes then the plan is changed to fit the new time. The berthing plan includes the number of tug boats and pilots according to the shipping agent's request in the berthing order as revised by the port authority. So the port decides about which tug boats and pilots are to be assigned for the arriving ship. The port also decides on a suitable berth which will fit the ship's depth and dimensions, also considering the type of shipment that needs to be discharged.

Once the ship arrives to the outer anchorage of the port the ship's captain notifies the tower of the port about his arrival and requests tugging. The captain is requested to enter the inner anchorage and wait until the pilots with the tug boats arrive. Computation of fees is based on the number of movements the pilots need in tugging the ship to the berth (the captain's navigational role having ended at this stage). 
When the parties in the port receive a copy of the manifest, each one of them starts planning to receive the shipment. The container handling company plans the equipment (cranes and forklift trucks) and workers it will need to move the shipment from ship to dock then to the yards. Use of the yards is planned by the company in the yard plan, so that each container is sent to its designated place based on the time of its departure. The containers are in two main sizes (40 and 20 feet) and they are arranged in a way that allows the ones which will leave early to be on the top in order to minimise the number of shifts when handling them. When the ship arrives in the port the yard plan is activated.

The stevedoring company also starts planning equipment and workers based on the type of (general) cargo arriving into the port. The warehouses prepare vacant areas to receive the arriving cargo. Some types of cargo will not fit in the warehouses and are stored in the outer area. The customs plans the employees needed to inspect imported cargo and a weekly schedule of inspection.

After the ship arrives at the berth, the captain releases a final copy of the manifest in addition to the bay plan. The container handling company begins discharging the ship according to the bay plan, and so does the stevedoring company. If the ship carries both types of shipment (containers and general cargo) both can be discharged at the same time using the designated equipment and workers. Each container is taken to its planned place and the general cargo is taken to the warehouses. Warehouses receive the cargo and begin moving them to their planned places in the warehouse.

Containers in general arrive at the port with the shipping agent's seal on them; this seal is not opened until the customs inspection starts. The owner or the shipping agent has filled out a customs form in advance of the ship's arrival, which specifies the exact number and types of shipments. Using this customs form the customs decide upon the number of units to be inspected, according to the declared figures, and sets the date of inspection. The owner or shipping agent goes to the tests department and informs them of the date and time of inspection.

The inspection committee consists of representatives from the customs and tests departments, a representative of the container handling company and the owner or shipping agent. When the cargo on the ship arrives to the inner anchorage, the tests department makes a preliminary testing by checking the cargo on the ship before berthing takes place. This happens with animals and crops (including wood), in order to avoid the introduction of any diseases.
The customs officers open the seal on the container and start to count and compare the shipment type with the invoices and the manifest. A sample is taken and further tests take place in the laboratory. If the customs check fails, then the owner has to pay a penalty fee, or can make a customs appeal and repeat the process. If the results of the test are negative then the shipment is refused; the owner can make a test appeal and request to repeat the tests. After the sample is taken the customs officer locks the container. If customs check is positive (compatible), the customs department waits for the results from the tests department.

When the tests results are approved by the tests department the owner is requested to take the results to the customs department. The customs department requests the owner or the shipping agent to pay the customs duty (percentage determined by the customs department) multiplied by the number of units imported. The owner or shipping agent pays all the fees required and goes back to the customs department in order to stamp the customs form for releasing his shipment.

The customs release is now taken by the owner. The owner may open the container in the port and take the cargo on to the trucks without a container, or can take the container closed on the truck and out of the port.

Trucks are identified by their companies to the port, so that they can be allowed to enter the port when they arrive at the gate. Trucks pick up the cargo and move back towards the gate. At the gate there are two personnel, one from the customs and the other from the police, to check the shipment's customs release and other documents.

\section{Exported goods}

The processes for handling exported goods are much simpler than those for imported goods. The owner of the shipments requests the tests department to take a sample of the exported cargo and test it in the laboratory. If the results are positive then the shipment will be allowed to pass and if it is negative then the shipment is refused. When the shipment is approved by the tests department the owner requests the customs department to inspect the shipment. This may take place in two ways. The shipment may be inspected when it arrives at the port and then be sealed by the shipping agent in the customs area after checking of documents. In this case the shipment is checked by the tests department before it leaves the customs area. Alternatively, the containers can be sealed outside at the manufacturer's premises, all the inspection and test procedures having taken place there. In this case the shipment will pass 
from the port's gate to the customs yard without inspection or tests, and then from the yard to the ship. There is no need to store the exported shipments in the yard since they are taken to the ship directly after they enter the gate. The trucks also arrive together, so that whenever a shipment arrives at the port and is allowed to enter, it is taken to the ship in sequence of arrival.

General

In general the port's income, other than the customs fees, comes from the following sources: ship handling (number of movements by tug boats and pilots), shipment handling (number of movements for each container), fees for use of yards and warehouses, and fees for tests, for weighing shipments, and for exceeding weight limits.

The focus in this study will be on containers rather than on general cargo for simplicity since diverse methods are used to handle and store different kinds of general cargo. This approach is justified by the fact that ports in general are moving towards containerisation, and handling bigger ships in bigger docks.

\section{Business process modelling}

\subsection{The purpose of process modelling}

It should be clear from the previous section that Alexandria Port has a number of departments, each of which is responsible for carrying out particular tasks or activities. The various activities and their interconnections can be understood better by drawing them out in a process model.

In modelling processes, it is important to select an appropriate method. A method that links business process design to process implementation widens the scope for communication between different parties involved in a process [11]. Business modelling is difficult because of the complexity of business [9]. The flow of work in any business is dynamic and uncertain. A process model provides a highlevel abstraction with which to visualise patterns in the business.

Process modelling can be used to break an organisation's activity down into small processes made up of actions and interactions. The modelled processes can then be analysed and perhaps improved. New processes can be designed and old ones altered. With the support of business process management software, processes in a model can be enacted to become real processes in the organisation.

\subsection{An overview of the Riva method}

The Riva method of business process modelling [6] is business-oriented rather than softwareoriented, in that it focuses on the management of business entities through the actions and interactions of different roles, rather than on a reduction of business to logic.

The method combines two forms of diagramming, process architecture diagramming and role activity diagramming. A process architecture diagram shows several or all of the business processes in an organisation, and how they relate to one another. A role activity diagram shows, for a single process, the activities within roles and the interactions between them. In this paper, we will develop an initial process architecture diagram but will not go on to depict the internal structure of individual processes.

In process architecture diagramming, the aim is to find and draw those processes which act on key objects or entities that the organisation must deal with. These objects called Essential Business Entities (EBEs). An EBE could be a product or service provided by the organisation, an internal or external customer, or it could just be things the organisation has to deal with during its day, or otherwise 'cannot get away from'. Ould suggests that organisations in the same line of business have to deal with the same EBEs. Organisations are also occupied with objects that are not fundamental to the business, but rather arise out of the way an organisation chooses to do its business. These Ould calls Designed Business Entities (DBEs). These may well differ between organisations in the same line of business.

Business entities (whether essential or designed) become units of work for an organisation, in the Riva method, when they are tracked and followed from the time they arrive in the organisation the time they leave. A unit of work (UOW) diagram shows how different units of work are involved with one another, or generate one another.

Building from the UOW diagram, each unit of work can then be treated as a case process within which roles, activities and interactions can be delineated in a role activity diagram. At a higher level, information flow and dynamic relationships between processes can be represented in a process architecture diagram. In addition to each unit of work being modelled as a case process, the flow of units of work through the organisation also needs to be modelled, as a case management process. Case processes and case management processes, and the interactions between them, are modelled in the process architecture diagram.

Once a process architecture diagram has been drawn for a business (or part of one) on the basis of the business entities it handles, it 
becomes possible to consider whether any improvement or streamlining of the business looks possible. Perhaps some processes could be enhanced, or dropped, or re-ordered. Perhaps departments could be restructured or responsibilities reallocated. The diagram permits a debate about change to commence. If sufficiently detailed, and given sufficient software support, the diagram could also serve as a basis for the enactment of new or changed processes in the organisation.

\section{Process modelling for Alexandria Port, Phase 1: Essential Business Entities}

According to the Riva method, a listing of EBEs captures the essence of the business of a particular kind of organisation, such as a port. All entities of interest are initially listed, and the list is subsequently reduced to keep just those judged 'essential'. The following list shows suggested EBEs for Alexandria Port.

- Entities that represent services offered by the organisation

Berthing plan: the planning of ships' berths by the berthing department, in advance of ships' arrival at port.

Yard plan: the planning of places for containers in the yard by the container handling department, in advance of the arrival of the shipment.

- Entities that are things the organisation 'cannot get away from'

Test: the testing of the sample from the shipment by the tests department, to ensure its compatibility with information in the invoices and the manifest.

Inspection: the checking of the shipment by the customs department against the invoices and the manifest.

Customs duty: the percentage of money calculated from the price of each imported unit multiplied by the number of units, giving the total amount of money paid by the owner to the customs department.

\section{- Entities that are external customers} to the organization

Shipping agent: representing the shipping company, which is responsible for the whole journey of the shipment from exporter to importer.

Owner: the person who owns the shipment and has to pay the money required for customs duty, testing, yard and warehouse charges, and by the agent.

\section{- Entities that are internal customer to the organisation}

Worker: including all the labourers involved in working with the shipment, such as crane and forklift drivers, customs officers, test technicians, gate personnel, departmental staff and warehousemen.

- Entities that arrive in the organisation from the customer

Berthing order: an order made by the shipping agent to request a berthing for his ship in the near future, indicating the number of tug boats and pilots needed and containing all the ship's details.

Bay plan: the plan that indicates the exact place of the shipment in the ship, especially the container locations in the hull.

Customs form: a form required by the customs department that the owner or the shipping agent (on behalf of the owner) has to fill in order to declare the type and amount of commodities in the shipment.

Customs appeal: an appeal made by the owner of the shipment about the customs counting or pricing for his shipment. It means that the owner wants to repeat the customs process once again.

Test appeal: an appeal made by the owner of the shipment about the test results of his shipment. It means that the owner wants to repeat the testing process once again.

Income: the expenses paid by the owner for receiving services from the port.

\section{- Entities that the organisation deals with day in, day out}

Shipment: the exported and imported containers carried by the ships from and to different ports.

Crane: used to load and discharge the shipment on to and from the ship.

Forklift truck: used to move the shipment from the dock to the yard.

Yard: the place where an imported container shipment stays in until it is released.

Warehouse: the place where general cargo is stored until it is released. 
Customs release: a form produced by the customs department to confirm that the shipment has passed the customs inspection and the tests successfully, and is ready to go out of the port's gate.

Truck: carries a shipment to the port or enters the port empty to load a shipment. After discharging a shipment it may load another one or go out empty.

Gate: controls the entrance and exit of any car, truck or person, to or from the port.

- Entities that the organisation keeps information on in its information system

Ship: carries the shipment from and to the port.

Manifest: contains all the details about the shipment carried on the ship. The original copy should be delivered no more than 24 hours after the ship's arrival by the captain of the ship. The primary copy is sent before the ship's arrival by the shipping agent but may not be accurate.

The list of entities above may contain some that are not truly derived from the essence of the business. Ould suggest some tests for distinguishing EBEs from secondary entities.

- It should be possible to write 'a' or 'the' in front of an EBE.

- Entities designed by the organisation as a way of carrying out its business are not EBEs.

- Entities which are mainly roles or departments in the organisation are not EBEs.

By applying these rules, it is possible to reduce the list of entities. Most of the plans and forms can be removed as business methods (but not berthing order or manifest because they carry vital information). Owner, worker, and shipping agent can be removed as roles. The list of fundamental entities or EBEs is then reduced to that shown in Table 2.

Table 2: Essential Business Entities at Alexandria Port
5. Process modelling for Alexandria Port, Phase 2: Unit Of Work diagram

In Riva, units of work are those entities that have a lifetime in which the organisation is interested. The organisation keeps track of such entities from the time they arrive till the time they leave. An entity does not become a unit of work if the organisation is not interested in tracking it through its lifetime, nor if someone else has the primary responsibility for looking after it.

On this basis, some EBEs from the list in Table 2 do not qualify as units of work. Crane, Forklift Truck, Yard, Warehouse, Truck and Gate are all important parts of the port's business, but Alexandria Port is concerned primarily with looking after and tracking shipments and ships, and not elements of the port infrastructure. A list of essential UOWs (EBEs that become UOWs) is shown as Table 3.

Ould notes that it is possible for new units of work to emerge around collections of other units or out of changes to existing units. In the present case, the best candidates for 'unseen' UOWs are produced by having to deal with changes to inspections, tests and manifests. This produces three additional units of work.

A UOW diagram can now be drawn (Figure 2), to show the connections between the various units of work, and in particular how they tend to produce or generate one another.

Table 3: Essential Units of Work at Alexandria Port

Ship
Shipment
Berthing Order
Manifest
Test
Inspection
Customs Duty
Income
Change to manifest
Change to test
Change to inspection

Ship
Shipment
Berthing Order
Manifest
Test
Inspection
Customs Duty
Income
Crane
Forklift Truck
Yard
Warehouse
Truck
Gate

Ship

Berthing Order

Manifest

Test

Inspection

Customs Duty

Income

Crane

Yard

Truck 


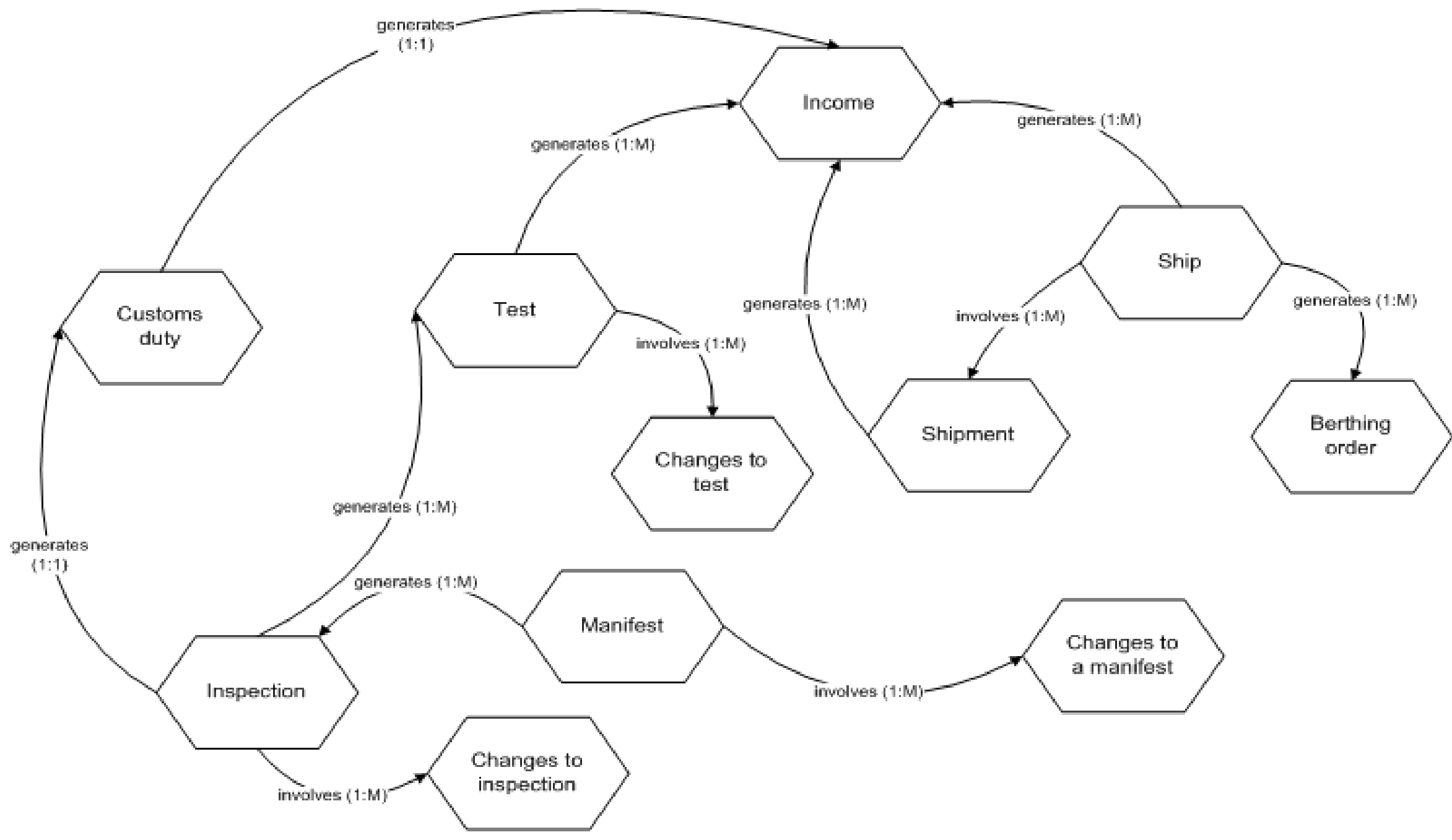

Figure 2: UOW diagram for Alexandria Port 
6. Process modelling for Alexandria Port, Phase 3: initial process architecture

In the final phase of modelling in this paper, the UOW diagram is elaborated into a process architecture diagram. This step, in Riva, involves distinguishing between case processes and case management processes. For each UOW there are one of each of these. The case process (CP) handles each instance of a UOW that arrives at the organisation. 'Handle a..(unit of work)' is commonly used to name a CP. The case management process (CMP) manages the flow of cases for each UOW. A new case arrives first at the CMP, which then requests the $\mathrm{CP}$ to start working with the case instance. Managing the flow of processes might mean batching CP instances, putting them in order, prioritising them, solving conflicts that might occur and so on. The CMP activates and starts CP instances and interacts with them if needed. When naming a CMP the phrase 'manage the flow of' is used.

Each process (whether CP or CMP) is represented by a rectangle. The arrows show how processes make a request to, start, or deliver to one another.

Figure 3 shows an initial process architecture for Alexandria Port, based on the UOW diagram in Figure 2 but elaborated to include CPs and CMPs for the UOWs, and the interconnections between them. 


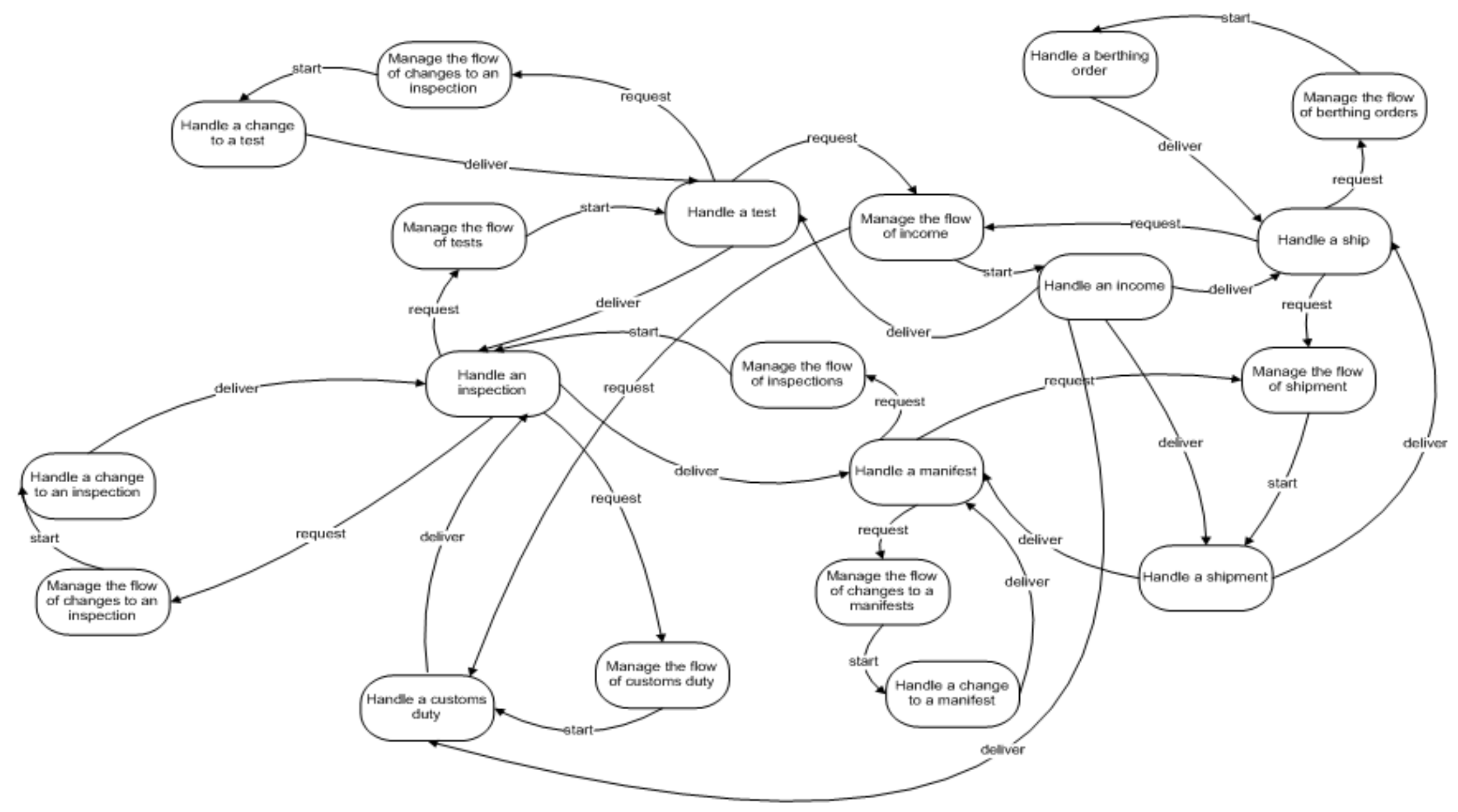

Figure 3: initial process architecture for Alexandria Port 


\section{Discussion and conclusion}

By following the Riva method, an initial process architecture has been derived for Alexandria Port that shows the interrelations among case processes and case management processes for dealing with the essential business entities that constitute units of work for the port. The diagram provides an overview of the fundamental business of the port and enables us to trace and query connections between different processes.

Once such a model is obtained, existing flows of work and information can be examined methodically, and a robust process redesign rooted in the essential business of the port becomes possible. Patterns of working that get in the way of the main business, or conversely promising innovations that could improve it, should be more easily identified if existing practices can be measured against the process architecture diagram. The decomposition of complex patterns of business activity into their constituent processes will make it easier to find the best approach to making wide ranging changes such as those associated with the introduction of new technology.

The present paper has only described the steps leading to the production of the initial process architecture. The completion of the architecture, and then elaboration of some of the processes using role activity diagramming, are still to be done. Only then will systematic analysis and evaluation of old and new processes be possible.

The process architecture developed for Alexandria Port is based on essential business entities, so should be generalisable to other ports, if the ideas behind Riva are right. We are carrying out a similar modelling exercise for the port of Sokhna, also in Egypt, partly to see whether the two process architectures are alike.

\section{References}

[1] Egyptian Government, 2008. Maritime Transport Sector (Alexandria). Retrieved June 2, 2008,

from://www.mts.gov.eg/english/inside e.aspx? main=ports\&level $1=$ commercial\&level $2=$ alex\&l evel3=berth

[2] Kia, M., Shayan, E. and Ghotb, F., 2000. The importance of information technology in port terminal operations. International Journal of Physical Distribution \& Logistics Management, 30(3/4), pp 331-344.

[3] Laine, J. and Vepsäläinen, A., 1994. Economies of speed in sea transportation. International Journal of Physical Distribution \& Logistics Management, 24(8), pp 33-41.

[4] López, R. and Poole, N., 1998. Quality assurance in the maritime port logistics chain: the case of Valencia, Spain. Supply Chain Management, 3(1), pp 33-44.

[5] Mei, Z. and Dinwoodie, J., 2005. Electronic shipping documentation in China's international supply chains. Supply Chain Management, 10(3), pp 198-205.

[6] Ould, Martyn A., 2005. Business Process Management: A Rigorous Approach. UK: British Computer Society.

[7] Paixão, A. and Marlow, P., 2003. Fourth generation ports - a question of agility? International Journal of Physical Distribution \& Logistics Management,33(4), pp 355-376.

[8] Tahar, R. and Hussain, K., 2000. Simulation and the analysis for the Kelang container terminal operations. Logistics information management,13(1), pp 14-20.

[9] Virine, L. and McVean, J., 2004. Visual modelling of business problems: workflow and patterns. In: R .G. Ingalls, M. D. Rossetti, J. S. Smith, and B. A. Peters, eds. Proceedings of the 2004 Winter Simulation Conference, Canada. Calgary Technology Center: Schlumberger Ltd, pp 1839-1844.

[10] Wang, J., Olivier, D., Notteboom, T. and Slack, B., 2007. Ports, Cities and Global Supply Chain. UK (Hampshire): Ashgate Publishing Limited.

[11] White, S., 2004. Business Process Management Initiative (BPMI): Business Process Modelling Notation (BPMN). Retrieved February 18, 2008, from://www.bpmi.org. 